\title{
A biphasic action of estradiol on estrogen and progesterone receptor expression in the lamb uterus
}

\author{
Ana MeIKLE ${ }^{\mathrm{a}, \mathrm{b} *}$, Mats Forsberg ${ }^{\mathrm{b}}$, Lena SAHLIN ${ }^{\mathrm{c}}$, Britt MASIRONI ${ }^{\mathrm{c}}$, \\ Celia TASENDE ${ }^{\mathrm{a}}$, Marcelo RodríGUEZ-PIÑón ${ }^{\mathrm{a}}$, Elsa G. GARÓFALO ${ }^{\mathrm{a}}$ \\ ${ }^{a}$ Biochemistry, Molecular and Cellular Biology, Veterinary Faculty, Montevideo, Uruguay \\ ${ }^{\mathrm{b}}$ Clinical Chemistry, Centre for Reproductive Biology, Swedish University \\ of Agricultural Sciences, Uppsala, Sweden \\ ${ }^{c}$ Division for Reproductive Endocrinology, Department of Woman and Child Health, \\ Karolinska Institutet, Stockholm, Sweden
}

(Received 21 December 1999; accepted 20 April 2000)

\begin{abstract}
Regulation of the uterine expression of estrogen and progesterone receptors was studied in 20 three-month-old lambs that were not treated or treated with estradiol-17 $\beta$. Determinations of receptors were performed by binding assays in the nuclear and cytosolic fractions, receptor mRNAs by solution hybridization, and estrogen receptor protein by an enzyme-immunoassay. Estradiol treatment decreased the receptor binding capacity of both receptors and the levels of immunoreactive estrogen receptor $12 \mathrm{~h}$ after injection in the absence of decreased receptor mRNAs, suggesting that the initial decrease is due to degradation of the proteins or that mRNAs are translated into new receptor proteins at a reduced rate. The mRNA levels increased after estradiol treatment suggesting that the replenishment phase consists of synthesis of new receptors rather than recycling of inactivated receptors.
\end{abstract}

estrogen / progesterone / receptor / uterus / lamb

Résumé - Action biphasique de l'œstradiol sur l'expression des récepteurs aux ostrogènes et à la progestérone dans l'utérus de l'agnelle. La régulation de l'expression des récepteurs aux ostrogènes et à la progestérone au niveau de l'utérus a été étudiée chez des agnelles immatures âgées de 3 mois $(n=20)$, traitées et non traitées avec œstradiol-17 $\beta$. Les déterminations des récepteurs ont été faites par des essais de liaison dans les fractions nucléaires et cytosoliques, les ARNm des récepteurs par la méthode d'hybridation en solution et la protéine du récepteur aux œstrogènes par un essai immuno-enzymatique. Le traitement à l'œstradiol réduit la capacité de liaison des deux récepteurs et les niveaux des récepteurs aux œstrogènes immunoréactifs $12 \mathrm{~h}$ après l'injection en absence d'une diminution des ARNm des récepteurs, suggèrent que la réduction initiale est due à la dégradation des

\footnotetext{
* Correspondence and reprints
}

E-mail: anamei @ adinet.com.uy 
protéines ou à une traduction à taux réduit des $\mathrm{ARNm}$ dans des nouveaux récepteurs. Les niveaux augmentés des ARNm après le traitement à l'œstradiol suggèrent que la phase de remplissage consiste en la synthèse des nouveaux récepteurs plutôt qu'au recyclage des récepteurs inactivés.

œstrogène / progestérone / récepteur / utérus / agnelle

\section{INTRODUCTION}

The main actions of estrogens (E) and progesterone $(\mathrm{P})$ are mediated via their intracellular receptors, estrogen and progesterone receptors (ER and PR), respectively. These ligand-activated transcription factors transduce the hormone signals into specific changes in gene expression. An example of this action is the regulation of the expression of their own receptor; the E-receptor complex stimulates both ER and PR gene expression in uteri of several mammalian species, while the P-receptor complex reduces levels of both receptors [4]. This is displayed by the variations in the concentrations of uterine sex steroid receptors [25, $31]$ as well as their respective mRNAs during the estrous cycle of the sheep $[27,35]$.

Previous studies demonstrated that ER and PR are present in high concentrations in different uterine layers in prepubertal lambs [7], and that these receptor proteins are physiologically active before ovarian cyclicity begins [22]. Treatment with $\mathrm{P}$ decreased concentrations of both receptors [22], and this down-regulation has also been reported for sheep and adult females of other species $[16,17,32,36]$. Treatment with estradiol-17 $\beta$ (E2) also decreased concentrations of uterine ER and PR in lambs [22], which was unexpected since it is different from previous findings in adult ewes in which such a treatment caused up-regulation of the steroid receptors $[32,36]$.

Down-regulation of receptor expression may be the consequence of inactivation of the receptors, inhibition of receptor synthesis, and/or stimulation of the receptor turnover. It has been suggested that the loss of hormone-binding capacity may be due to receptor inactivation by dephosphorylation [26]. Inhibition of receptor synthesis was shown in rat uteri and MCF-7 cells, where E2 induced suppression of ER mRNA a few hours after treatment [1, 39]. Furthermore, the apparent decrease in the total number of measurable binding sites after a hormone challenge in rat uteri is due to degradation of the protein $[20,39]$. This "processing" found in the regulatory action of E2 on its receptor was also reported in the same specie by other authors [3, 13, 33], but no data as such has been reported for sheep. The heterologous down-regulation observed also in PR uterine expression after E2 treatment in lambs [22] was unforeseen, and no mechanism of action for this has yet been proposed.

The present study was designed to examine estradiol regulation of the uterine expression of ER and PR in prepubertal lambs by measuring binding activity in cytosolic and nuclear fractions and the mRNA levels of both receptors at different times after E2 treatment. In addition, ER dynamics were also studied by measuring the receptor protein using an enzyme immunoassay.

\section{MATERIALS AND METHODS}

\subsection{Experimental design}

Twenty 3-month-old female Corriedale lambs (body weight, mean \pm SEM: $17.4 \pm$ $0.6 \mathrm{~kg}$ ) born during the non-breeding season were used. The lambs were kept under natural environmental conditions and were 
allowed to nurse freely during the experiment. Animals were randomly assigned to five groups ( $n=4$ each). Lambs were not treated (Group I, controls) or treated with one (Groups II and III), two (Group IV), or three (Group V) i.m. injections of estradiol$17 \beta$ (E2) $\left(1 \mu \mathrm{g} \cdot \mathrm{kg}^{-1}\right.$, Sigma, St. Louis, MO, USA) in a corn oil vehicle at intervals of $24 \mathrm{~h}$. The lambs were slaughtered $12 \mathrm{~h}$ (Group II) and $24 \mathrm{~h}$ (Groups III, IV, V) after the last injection. Animals in groups IV and $\mathrm{V}$ were catheterized in the jugular vein and blood samples for E2 determinations were collected every $4 \mathrm{~h}$ starting just before treatment until time of sacrifice. In the rest of the groups, blood samples from the jugular vein were taken at the time of slaughter. Blood samples were centrifuged and serum was stored at $-20{ }^{\circ} \mathrm{C}$. Estradiol-17 $\beta$ levels were determined by a ${ }^{125}$ I RIA (Estradiol double antibody, KE2D, Diagnostic Products Co, Los Angeles, CA, USA), and the data has been published previously [23]. At slaughter, the uteri were dissected at $4{ }^{\circ} \mathrm{C}$ and weighed. To obtain uniform samples of the whole uterine wall (including myometrium, endometrium, and caruncles) the upper, middle, and lower portions of the uterus were selected. The upper zone was defined as the third portion of the uterine horn next to the oviduct, the lower zone as the third portion next to the cervix, and the middle zone as the area in between. The tissues were frozen in liquid nitrogen and stored at $-80{ }^{\circ} \mathrm{C}$ until assayed. The upper uterine zone was used for determinations of ER and PR concentrations (by binding assays); the middle zone was used for determinations of mRNA levels of ER and PR (by solution hybridization); and the lower uterine zone was used for determination of ER protein levels (by an enzyme immunoassay). Recently, a novel subtype of ER, named beta, was discovered [14]. To our knowledge, the ER $\beta$ has not yet been described in ovine tissues. In the ligandbinding assay, the "old" ER - now named alpha - and ER $\beta$ are determined. The EIA does not cross-react with human ER $\beta$
(Abbott Lab., personal communication), and the mRNA determination is specific for ER $\alpha$ mRNA [10].

\subsection{Extraction and assays of steroid receptors}

It is now accepted that ER and PR are situated predominately in the nucleus in vivo and that the cytosolic receptors represent an artifact after cellular disruption during homogenization of the tissues [29]. Since receptors are tightly bound in the nuclear fraction after a hormone challenge and a high salt concentration is required for their extraction [4], we performed binding assays in both the cytosolic and nuclear fractions in samples of the upper uterine zone of each animal. The term cytosolic receptors is used in this study to indicate receptors found in the supernatant fraction of a tissue homogenate after high-speed centrifugation. Nuclear receptors refer to the receptors present in a $0.4 \mathrm{M} \mathrm{KCl}$ extract of the nuclear pellet. The expression of total receptors refers to the sum of the cytosolic and nuclear receptors.

Cytosolic receptor assays. The ER and $\mathrm{PR}$ receptor determinations were performed in the cytosolic fractions by a binding assay described previously [7, 37]. Briefly, the cytosolic fraction was incubated with 5 to 6 increasing concentrations of $\left[2,4,6,7-{ }^{3} \mathrm{H}\right]$ estradiol-17 $\beta 86 \mathrm{Ci} \cdot \mathrm{mmol}^{-1}(0.3-15 \mathrm{nM})$, or ${ }^{3} \mathrm{H}-\mathrm{ORG}-2058$, (16 $\alpha$-ethyl-21-hydroxy19-nor $\left[6,7-{ }^{3} \mathrm{H}\right]$ pregn-4en-3,20-dione $40 \mathrm{Ci} \cdot \mathrm{mmol}^{-1}(0.5-30 \mathrm{nM})$ for $18 \mathrm{~h}$ with or without 200-fold molar excess of either unlabeled diethylstilbestrol or unlabeled ORG2058, respectively. The separation of free hormone was by dextran-coated charcoal and radioactivity was measured by liquid scintillation counting. Protein concentrations were determined by the method of Lowry et al. [18], using BSA as the standard. Specific binding data from the ligandbinding assay were obtained by subtracting nonspecific binding from total binding. 
A linear regression test of the inverse Scatchard model [2] analysis of the data was performed. This provided the dissociation constant and the concentration of receptor sites at the intercept, B max, expressed in fmol $\cdot \mathrm{mg}^{-1}$ protein and fmol. $\mathrm{mg}^{-1}$ tissue.

Nuclear receptor assays. A nuclear exchange assay for ER and PR was performed in every sample as described by Clarke et al. [5]. To validate exchange conditions we conducted experiments in uteri of two adult ewes (data not shown). After a centrifugation at $1000 \times g$ for $15 \mathrm{~min}$, the pellet was resuspended with TEDG buffer, and an equal volume of TEDG containing $0.8 \mathrm{M} \mathrm{KCl}$ was added. The tubes were vortexed at 5 -min intervals for $30 \mathrm{~min}$ at $4{ }^{\circ} \mathrm{C}$ and centrifuged at $10000 \times g$ for $10 \mathrm{~min}$. The supernatant containing salt-extracted nuclear ER and PR was then used for the nuclear exchange assay. The incubation procedure with the series of dilutions of the respective hormones for total and nonspecific binding was exactly as described for the cytosolic receptors, except that incubation was at $20^{\circ} \mathrm{C}$ for $2 \mathrm{~h}$. After cooling at $4{ }^{\circ} \mathrm{C}$, the bound fractions were separated by dextran charcoal as described above. Nuclear receptors are expressed in relation to the concentration of the tissue (fmol. $\mathrm{mg}^{-1}$ tissue). Groups I and II $(n=8)$ were used to study receptor affinity and capacity by Scatchard analysis. It was found that the receptors were saturated in the presence of $15 \mathrm{nM}{ }^{3} \mathrm{H}-\mathrm{E} 2$ for ER and $16 \mathrm{nM}$ of ${ }^{3} \mathrm{H}-\mathrm{ORG}-2058$ for PR. In the rest of the groups (III, IV, and V), ER and PR concentrations were measured by saturation analysis. Triplicate aliquots $(100 \mu \mathrm{l})$ of the nuclear fraction were added to tubes containing $5 \mu \mathrm{l}$ of labeled ligand at the saturating concentrations for determinations of the total bound ${ }^{3} \mathrm{H}$-labeled ligand. Another series of tubes was incubated with an excess of 200-fold molar of either unlabeled DES or unlabeled ORG-2058 for determination of nonspecific binding. The incubation procedure and separation was exactly as for Groups I and II.

\subsection{Hybridization analysis of mRNA}

A solution hybridization assay of specific ovine mRNAs for ER and PR was performed in samples of the middle uterine zone. The method was essentially performed as in Persson et al. [30]. In short: total nucleic acids (TNA) were prepared by digesting homogenized (Ultra-turrax) tissues (200-250 mg) with proteinase $\mathrm{K}$ in a buffer containing SDS, followed by subsequent extraction with phenol-chloroform. The concentration of DNA in the TNA samples was measured fluorometrically at the wavelength $458 \mathrm{~nm}$ with Hoechst Dye 33258 [15]. For measurements of specific mRNA, probes were synthesized in vitro and radiolabeled with ${ }^{35} \mathrm{~S}-\mathrm{UTP}$ (Amersham, Buckinghamshire, UK), as described by Melton et al. [24] using reagents supplied by Promega Biotech (Madison, WI, USA). The hybridization probes used for ER mRNA and PR mRNA determinations were derived from plasmids containing 360 or 314 bp cDNAs from the ovine ER and PR, respectively, kindly supplied by Dr. N. Ing, Texas A \& M University, TX, USA [12]. Restriction of the vector (pGEM4Z) containing a fragment of the oER cDNA with EcoRI allows the synthesis of an anti-sense RNA probe using T7 RNA polymerase. Restriction of the vector (pCRII) containing a fragment of the oPR cDNA with HindIII allows the synthesis of an anti-sense RNA probe using T7 RNA polymerase. The ${ }^{35} \mathrm{~S}-\mathrm{UTP}-$ labeled cRNA was hybridized (20 000-40 $000 \mathrm{cpm}$ per incubation) at $70{ }^{\circ} \mathrm{C}$ to TNA samples as described by Mathews et al. [19]. Incubation was performed in duplicates at two different concentrations, in microcentrifuge tubes (Treff AG, Switzerland) in a volume of $40 \mu \mathrm{l} \mathrm{con-}$ taining $0.6 \mathrm{M} \mathrm{NaCl}, 20 \mathrm{mM}$ Tris- $\mathrm{HCl}(\mathrm{pH}$ 7.5), 4 mM EDTA, $0.1 \%$ SDS, $0.75 \mathrm{mM}$ DTT, and $25 \%$ formamide under two drops of paraffin oil. After overnight hybridization, samples were treated with $1 \mathrm{ml}$ RNase buffer containing $0.3 \mathrm{M} \mathrm{NaCl}, 10 \mathrm{mM}$ Tris$\mathrm{HCl}$ (pH 7.5), 2 mM EDTA, $40 \mu \mathrm{g}$ RNase 
A, 118 U RNase T1 (Boeringer-Mannheim, Mannheim, Germany), and $100 \mu \mathrm{g}$ calf thymus DNA for $45 \mathrm{~min}$ at $37^{\circ} \mathrm{C}$ to digest unhybridized RNA. Labeled hybrids protected from RNase digestion were precipitated by addition of $100 \mu \mathrm{l} 6 \mathrm{M}$ trichloroacetic acid and collected on filters (Whatman GF/C). Radioactivity was determined in a liquid scintillation counter. All the samples from the experiment were determined in the same assay, and the intra-assay CV was $16 \%$ for ER mRNA and $9.2 \%$ for PR mRNA. Receptor mRNA levels were expressed as cpm in relation to DNA content $\left(\mathrm{cpm} \cdot \mu \mathrm{g}^{-1} \mathrm{DNA}\right)$.

\subsection{Enzyme immunoassay (EIA) of ER protein}

Samples of the lower uterine zone of each animal were cut with a scalpel into small pieces and freeze-dried for $48 \mathrm{~h}$. The tissues were transferred to a glass tube and further finely chopped. The receptors were extracted from the tissues with $0.4 \mathrm{M} \mathrm{KCl}$ in TEM-SH buffer (10 mM Tris-HCl, $1.5 \mathrm{mM}$ EDTA, $5.0 \mathrm{mM} \mathrm{Na} \mathrm{MoO}_{4}, 1 \mathrm{mM}$ monothioglycerol, $\mathrm{pH} 7.4)$, w/v 1:10, for $30 \mathrm{~min}$ (mixed every $5 \mathrm{~min}$ ). After a $5000 \times g$ centrifugation for $20 \mathrm{~min}$, the supernatants were removed, and the pellets were washed again for $30 \mathrm{~min}$ (mixing every $5 \mathrm{~min}$ ) and recentrifuged under the same conditions as previously. Finally, the supernatants from both centrifugations were pooled and centrifuged for $65 \mathrm{~min}$ at $192000 \times g$. The receptor determinations were performed in duplicates by an enzyme immunoassay for humans (ER-EIA monoclonal kit, Abbott Lab., Chicago, IL, USA). According to the information supplied with the kit, the assay measures both occupied and unoccupied estrogen receptor proteins. The monoclonal antibody used was H222 (Abott Lab., personal communication), which was previously used in ovine uterus [35]. Protein determinations were done according to Lowry et al. [18], and receptor concentrations were expressed in relation to protein content. The receptor concentrations were based on the standard curve for human ER included in the kit. The intra and inter-assay $\mathrm{CV}$ were less than $10 \%$.

\subsection{Statistical analysis}

Data of receptor and mRNA determinations were analyzed using the General Linear Model procedure for analysis of variance (Statistical Analysis Systems Institute Inc., 1994). Data are presented as leastsquare means \pm standard errors for each treatment group. The level of significance was $P<0.05$, except where otherwise specified. Spearman's correlation coefficients were calculated to study relationships between variables. ER and PR determination by binding assays, ER protein determination by EIA as well as mRNAs of ER and $\mathrm{PR}$ are expressed as percentages of the control group average to show changes induced by the treatment.

\section{RESULTS}

Maximum estradiol levels were detected in the first bleeding after the injection $(4 \mathrm{~h}$, range: 103 to $\left.250 \mathrm{pmol} \cdot \mathrm{L}^{-1}\right)$, but levels at slaughter time were baseline (12 to $\left.15 \mathrm{pmol} \cdot \mathrm{L}^{-1}\right)$ in the treated groups [23]. Estradiol induced changes in gross characteristics of the uteri by increasing the size and redness. Uterine weight $(\mathrm{g})$ increased gradually and Group I (3.21 \pm 0.62$)$ had less uterine weight than Groups IV (6.16 \pm 0.73$)$ and $\mathrm{V}(6.38 \pm 0.95)$, but was not different from Group II $(5.28 \pm 1.30)$ and III (5.67 \pm 1.18).

The cytosolic protein extraction was similar for all the assays (the correlation of protein content $\left(\mathrm{mg} \cdot \mathrm{mL}^{-1}\right)$ vs. tissue concentration $\left(\mathrm{g} \cdot \mathrm{mL}^{-1}\right)$ was $r=0.8896, n=20$; $P<0.003$ ), but there was a higher content of protein per amount of tissue (mg cytosolic protein per $\mathrm{g}$ tissue) in Groups II (12 h), 
III (24 h), and IV (48 h) (mean \pm SEM: 50.8 $\pm 3.7 ; 59.2 \pm 4.5 ; 56.9 \pm 3.2)$ than in groups I (controls) and V (72 h) $(39.9 \pm 1.4 ; 41.1 \pm$ 1.2), $P<0.05$.

Dissociation constants $(\mathrm{Kd}, \mathrm{nM})$ for cytosolic ER were similar (mean \pm SEM: $0.31 \pm 0.05, n=16$ ), except in Group V, which had higher values $(1.45 \pm 0.21, n=4$; $P<0.05)$. An increase in ER Kd values after E2 treatment has been found previously in rat uteri [21], but the biological implication of these differences in binding affinity is not clear. The affinity for cytosolic PR was similar in all groups $(0.65 \pm 0.07 \mathrm{nM}$, $n=20$ ). The binding affinities of both ER and PR were similar to those found in different physiological situations in sheep $[6,7,31,32,37]$. Nuclear ER Kd (0.47 \pm $0.08 \mathrm{nM}, n=8$ ) had an affinity similar to that of the cytosolic receptor. The $\mathrm{Kd}$ of nuclear PR $(1.62 \pm 0.28 \mathrm{nM}, n=8)$ was higher than the cytosolic $\mathrm{Kd}(P<0.05)$.

The overall effect of group was significant for all variables analyzed $(P<0.001)$. ER and PR cytosolic concentrations determined by binding assays are shown as the percentage of the control group (Fig. 1). ER and PR cytosolic concentrations for the controls (mean \pm SEM, fmol. $\mathrm{mg}^{-1}$ protein) were $825 \pm 161$ and $1530 \pm 248$, respectively. Estradiol treatment decreased the ER levels $12 \mathrm{~h}$ (Group II) and $24 \mathrm{~h}$ (Group III) after the first injection $(P<0.05)$, and the levels were increased $24 \mathrm{~h}$ after two (Group IV) and three (Group V) injections but were not different from the levels in the control group. PR followed a similar pattern, but there was a net increase in PR levels $24 \mathrm{~h}$ after the third injection (Group V) compared to the control group $(P<0.05)$.

In order to compare ER and PR determinations in both cytosolic and nuclear fractions, receptor contents are expressed as fmol. $\mathrm{mg}^{-1}$ tissue. There was a high correlation between ER concentrations in the cytosolic fraction, expressed as fmol. $\mathrm{mg}^{-1}$ protein and fmol. $\mathrm{mg}^{-1}$ tissue $(r=0.9869$, $n=20 ; P<0.001)$, and a similar correlation was found for PR concentrations $(r=0.9771, n=20 ; P<0.001)$. Although the receptor data expressed as fmol. $\mathrm{mg}^{-1}$ tissue led to different statistics between groups than when expressed as fmol. $\mathrm{mg}^{-1}$ protein, the patterns during the treatment

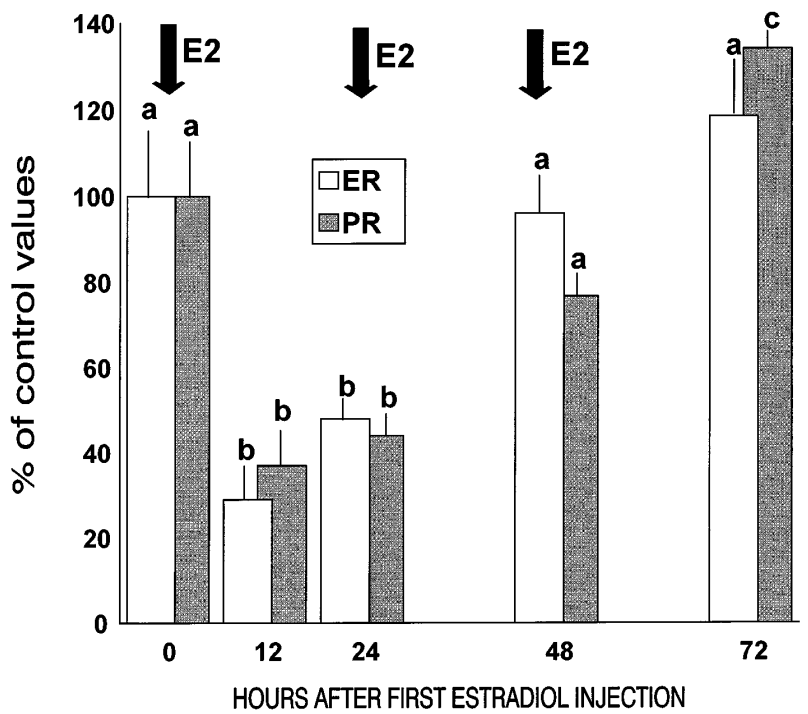

Figure 1. The concentrations of estrogen receptor (ER) and progesterone receptor (PR) determined by binding assays in the uterine cytosolic fraction of control lambs $(0 \mathrm{~h})$, and lambs treated with one (12 h, $24 \mathrm{~h}$ ), two (48 h), or three (72 h) estradiol (E2) injections (arrows). Values are expressed as a percentage of the control group. Bars (least square means + SEM) within the same series marked with different letters are significantly different $(P<0.05)$ 
Table I. Concentrations (fmol $\cdot \mathrm{mg}^{-1}$ tissue, least square means \pm SEM) of nuclear, cytosolic, and total estrogen (ER) and progesterone receptors (PR) by binding assays in uteri of control and E2-treated lambs.

\begin{tabular}{llllllll}
\hline Group & \multicolumn{3}{c}{ Estrogen receptor } & & \multicolumn{3}{c}{ Progesterone receptor } \\
\cline { 2 - 3 } \cline { 7 - 8 } & Nuclear & Cytosolic & Total & & Nuclear & Cytosolic & Total \\
\hline I (control) $(n=4)$ & $2.6 \pm 0.7^{\mathrm{a}}$ & $33.0 \pm 6.2^{\mathrm{ac}}$ & $35.6 \pm 6.1^{\mathrm{ad}}$ & & $2.2 \pm 0.4^{\mathrm{ac}}$ & $61.7 \pm 12.4^{\mathrm{a}}$ & $63.7 \pm 12.2^{\mathrm{a}}$ \\
II $(12 \mathrm{~h})(n=4)$ & $3.1 \pm 0.6^{\mathrm{a}}$ & $12.2 \pm 3.7^{\mathrm{b}}$ & $15.3 \pm 3.9^{\mathrm{b}}$ & & $2.9 \pm 0.3^{\mathrm{a}}$ & $28.7 \pm 5.6^{\mathrm{b}}$ & $31.5 \pm 5.8^{\mathrm{b}}$ \\
III $(24 \mathrm{~h})(n=4)$ & $2.9 \pm 0.5^{\mathrm{a}}$ & $22.8 \pm 1.1^{\mathrm{bc}}$ & $25.2 \pm 1.2^{\mathrm{ab}}$ & & $1.0 \pm 0.3^{\mathrm{bd}}$ & $39.5 \pm 3.8^{\mathrm{b}}$ & $40.5 \pm 3.9^{\mathrm{b}}$ \\
IV $(48 \mathrm{~h})(n=4)$ & $6.8 \pm 0.9^{\mathrm{b}}$ & $44.9 \pm 3.2^{\mathrm{d}}$ & $51.7 \pm 4.0^{\mathrm{c}}$ & & $1.3 \pm 0.5^{\mathrm{bc}}$ & $66.9 \pm 4.4^{\mathrm{ac}}$ & $68.2 \pm 4.6^{\mathrm{ac}}$ \\
V $(72 \mathrm{~h}) n=4)$ & $3.3 \pm 0.4^{\mathrm{a}}$ & $39.9 \pm 4.0^{\mathrm{ad}}$ & $43.2 \pm 4.3^{\mathrm{cd}}$ & & $0.2 \pm 0.1^{\mathrm{d}}$ & $83.7 \pm 2.0^{\mathrm{c}}$ & $83.9 \pm 2.0^{\mathrm{c}}$
\end{tabular}

Values with different letters in a series are significantly different $(P<0.05)$.

were similar (Tab. I). The differences were probably a reflection of the different protein concentrations in the treated groups. Nuclear ER levels did not exceed $7 \mathrm{fmol} \cdot \mathrm{mg}^{-1}$ tissue in any group. Group IV $(48 \mathrm{~h})$ had a higher nuclear ER level than the other groups $(P<0.05)$. Nuclear PR levels did not exceed $3 \mathrm{fmol} \cdot \mathrm{mg}^{-1}$ protein in any group. Therefore, total receptor concentrations were mainly influenced by the receptors found in the cytosolic fraction. The total concentration of PR was positively correlated with the total concentration of $\mathrm{ER}(r=0.7654, n=20 ; P<0.001)$.

ER protein concentrations determined by EIA are shown as the percentage of the control group in Figure 2. The data showed a significant correlation with total ER content determined by binding assays ( $r=0.7085, n=20 ; P<0.001)$. ER levels determined by EIA decreased to about $20 \%$ of the control group $12 \mathrm{~h}$ after E2 treatment (Group II) but did not differ from the control
Figure 2. The uterine levels of total estrogen receptor (ER) determined by an enzyme immunoassay (EIA) of control lambs $(0 \mathrm{~h})$, and lambs treated with one (12 h, $24 \mathrm{~h})$, two $(48 \mathrm{~h})$, or three $(72 \mathrm{~h})$ estradiol (E2) injections (arrows). Values are expressed as a percentage of the control group. Bars (least square means + SEM) with different letters are significantly different $(P<0.05)$.

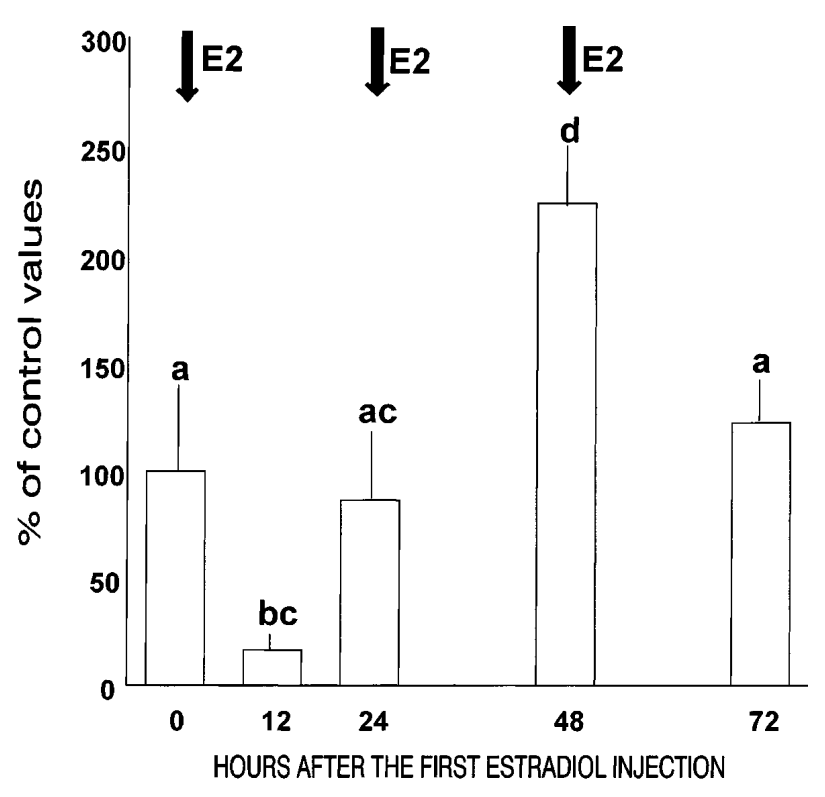


group at $24 \mathrm{~h}$ (Group III). At $48 \mathrm{~h}$ after the first E2 injection (Group IV), ER concentrations were more than 2-fold higher than in controls, but the levels returned to control values $72 \mathrm{~h}$ (Group V) after the initiation of the treatment.

Figure 3 summarizes the effects of estradiol on the mRNA levels of ER and PR. The control group is defined as $100 \%$, and the other groups are compared to the control group. There was an increase in mRNA levels $12 \mathrm{~h}$ after the first E2 injection (Group II), and levels remained high during the experimental period. Maximum levels (more than 3-fold the control values) were detected $48 \mathrm{~h}$ after the first $\mathrm{E} 2$ injection (Group IV). The levels of ER mRNA and PR mRNA were highly correlated $(r=0.8357, n=20 ; P<0.001)$.

\section{DISCUSSION}

The results confirm previous observations [22] that the prepubertal ewe has high uterine concentrations of physiologically active steroid receptors. The initial effect of estradiol on receptor levels was inhibitory, but the subsequent response was to increase receptor expression. The initial suppression on the binding capacity of ER and PR is different from the reported receptor up-regulation induced by estrogen in cyclic and ovariectomized ewes [25, 31, 32]. It has been suggested that $\mathrm{E} 2$ regulation of uterine ER in rat is dose dependent, as demonstrated by the positive and negative effects of low and high doses of E2 on ER concentrations, respectively [20]. The dose used in the present study $\left(1 \mu \mathrm{g} \cdot \mathrm{kg}^{-1}\right)$ has been considered to be physiological since it avoids pharmacological effects that may down-regulate the ER gene expression [10]; however, the same authors later found a temporal decrease in ER (determined by immunohistochemistry), in some of the uterine cell compartments in E2-treated ovariectomized ewes [11]. Since a loss of immunoreactive ER was found in the present study, we suggest that the initial decrease in receptor concentration after E2 treatment is due to a loss of the protein itself, instead of a reduction in the binding capacity for the steroid (receptor inactivation). This receptor processing was reported in rodents [20,39], and could be the result of an increase in the action of specific proteases or inhibition of receptor synthesis $[8,13]$. The latter cannot be explained by the ER mRNA levels since mRNA

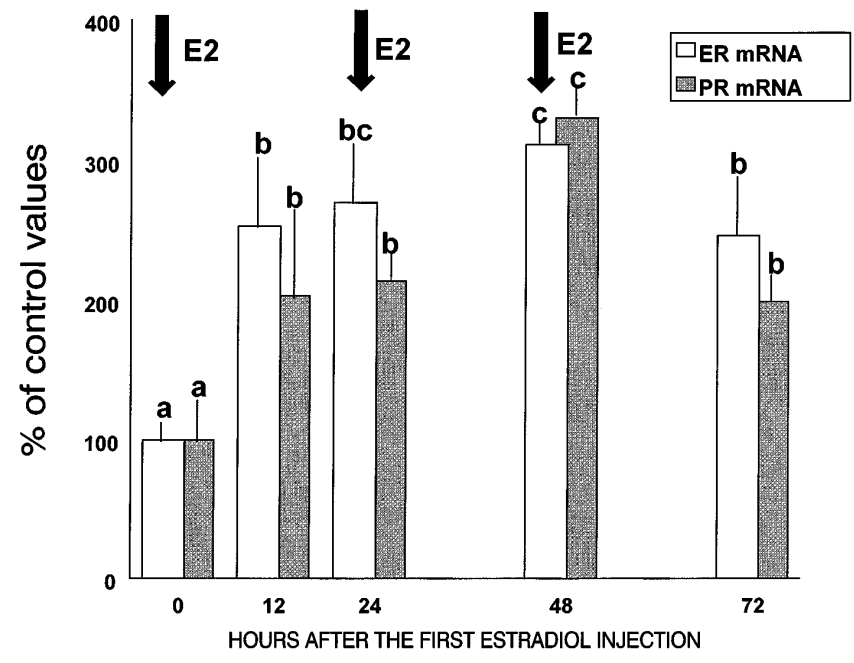

Figure 3. Uterine levels of ER mRNA and PR mRNA in control lambs $(0 \mathrm{~h})$, and lambs treated with one $(12 \mathrm{~h}$ $24 \mathrm{~h})$, two (48 h), or three $(72 \mathrm{~h})$ estradiol (E2) injections (arrows). Both mRNA levels are expressed as a percentage of the control group. Bars (least square means + SEM) within the same series with different letters are significantly different $(P<0.05)$ 
expression was not decreased $12 \mathrm{~h}$ after the first injection (when receptor concentration was minimal), but a reduction in the rate of translation into a new receptor protein can be proposed. This homologous down-regulation also found for other steroid receptors [4] might represent a feedback mechanism to limit the duration of the hormone action on the cell.

An interesting finding in this study was the suppression of PR expression by E2, which has not been described previously in sheep. The downregulation of PR by E2 has been scarcely reported, but studies performed in rabbit oviducts [9] and in rat uteri [28] suggested that differences in E2 regulation of PR may depend on the species, the tissues and/or the cell types. Even thought we measured only the binding activity of $\mathrm{PR}$, a mechanism of estrogen-induced receptor loss may exist for this protein as well.

The replenishment (recycling and/or de novo synthesis) of the receptors following hormone-induced depletion is an important factor for enabling the target tissue to respond to subsequent hormone stimulation. The 2- to 3-fold increase in ER mRNA and PR mRNA levels observed after E2 treatment suggests that the replenishment phase after hormone treatment consists of synthesis of new receptors rather than of recycling inactivated receptors. It is extremely difficult to find an internal control (or housekeeping gene) to use as a standard. Beta-actin and GAPDH mRNAs have been found to be affected by hormone treatment [12, 34]. Nevertheless, overall RNA synthetic activity has been found to be at a maximum at $12 \mathrm{~h}$ after E2 treatment in sheep [12] and this is consistent with the peak in protein concentration found $24 \mathrm{~h}$ after the first E2 injection in our study. Thus, since maximum concentrations of both mRNAs in the present experiment were observed $48 \mathrm{~h}$ after the first injection, it is likely that the changes in mRNA concentrations are specific. Ing et al. [12] reported a 5-fold increase in ER mRNA $24 \mathrm{~h}$ post-estradiol treatment, but no further increases were observed with a double challenge with E2 [40], supporting the findings in this study. In contrast, Zhou et al. [39] and Sahlin et al. [34], found a suppression of ER mRNA levels $8 \mathrm{~h}$ and $6 \mathrm{~h}$, respectively, after E2 treatment in rat uteri. Estradiol up-regulates the ER mRNA levels in endometrium and myometrium of ovariectomized ewes [12,38]. The increases in ER mRNA and PR mRNA levels in this study were similar to those reported in intact cyclic ewes $[27,35]$. In the present study, the changes in mRNA levels of ER and PR were consistent with the receptor concentrations.

In summary, the results of this study suggest that estradiol action on ER and PR expression is biphasic. The early effect on receptor processing may reflect an actual degradation of the receptor proteins. Thus, as supported by our data, the late replenishment phase seems to be the result of an increase in the synthesis of new receptors.

\section{ACKNOWLEDGMENTS}

The ovine ER and PR cDNA were a generous gift from N. Ing, Texas A \& M University, TX, USA. The authors want to thank P. Rubianes and I. Sartore for their technical assistance, S. Àkerberg for the EIA determinations and I. Tebot for translation of the French summary. We also want to thank H. Kindahl and H. Eriksson for constructive criticism of this manuscript and N. Lundeheim for statistical advice. The present study received financial support from the CSIC, the Veterinary Faculty and PEDECIBA, University of Uruguay, the Swedish Medical Research Council (grant 03972), and the Swedish University of Agricultural Sciences.

\section{REFERENCES}

[1] Borrás M., Hardy L., Lempereur F., El Khissiin A.H., Legros N., Gol-Winkler R., Leclercq G. Estradiol-induced down-regulation of estrogen receptor. Effect of various modulators of protein synthesis and expression, J. Steroid. Biochem. Mol. Biol 48 (1994) 325-336.

[2] Braunsberg H., Mathematical analysis of data from receptor assay, Recent, Results Cancer Res. 91 (1984) 18-31. 
[3] Cidlowski J.A., Muldoon T.G., The dynamics of intracellular receptor regulation as influenced by 17-beta estradiol, Biol. Reprod. 18 (1978) 234-246.

[4] Clark J.H., Schrader W.T., O’Malley B.W., Mechanisms of steroid hormones action, in: Wilson J.D., Foster D.W. (Eds.), Williams Textbook of Endocrinology, 8th ed., W.B. Saunders Philadelphia, 1992, pp. 35-90.

[5] Clarke I.J., Burman K., Funder J.W., Findlay J.K., Estrogen receptors in the neuroendocrine tissues of the ewe in relation to breed, season, and stage of the estrous cycle, Biol. Reprod. 24 (1981) 323-331.

[6] Findlay J.K., Clarke I.J., Swaney J., Colvin N., Doughton B., Oestrogen receptors and protein synthesis in caruncular and intercaruncular endometrium of sheep before implantation J. Reprod. Fertil. 64 (1982) 329-339.

[7] Garófalo E.G., Tasende C., Uterine estrogen and progesterone receptors in prepubertal ewes: distribution in myometrium, endometrium and caruncles, Vet. Res. 27 (1996) 177-183.

[8] Horwitz K.B., McGuire W.L., Nuclear mechanisms of estrogen action: effects of estradiol and antiestrogens on estrogen receptors and nuclear receptor processing, J. Biol. Chem. 253 (1978) 8185-8191.

[9] Hyde B.A., Blaustein J.D., Black D.L., Differential regulation of progestin receptor immunoreactivity in the rabbit oviduct, Endocrinology 125 (1989) 1479-1483.

[10] Ing N.H., Ott T.L., Estradiol up-regulates estrogen receptor- $\alpha$ messenger ribonucleic acid in sheep endometrium by increasing its stability, Biol. Reprod. 60 (1999) 134-139.

[11] Ing N.H., Tornesi M.B., Estradiol up-regulates estrogen receptor and progesterone receptor gene expression in specific ovine uterine cells, Biol. Reprod. 56 (1997) 1205-1215.

[12] Ing N.H., Spencer T.E., Bazer F.W., Estrogen enhances endometrial estrogen receptor gene expression by a posttranscriptional mechanism in the ovariectomized ewe, Biol. Reprod. 54 (1996) 591-599.

[13] Kassis J.A., Gorski J., On the mechanism of estrogen receptor replenishment: recycling, resynthesis and/or processing, Mol. Cell. Biochem. 52 (1983) 27-36.

[14] Kiuper G.G.J.M., Enmark E., Pelto-Huikko M. Nilsson S., Gustafsson J.A., Cloning of a novel estrogen receptor expressed in rat prostate and ovary, Proc. Natl. Acad. Sci. USA 93 (1996) 5925-5930.

[15] Labarca C., Paigen K., A simple, rapid, and sensitive DNA assay procedure, Anal. Biochem. 102 (1980) 344-352.

[16] Leavitt W.W., Okulicz W.C., McCracken J.A., Schramm W., Robidoux W.F. Jr, Rapid recovery of nuclear estrogen receptor and oxytocin receptor in the ovine uterus following progesterone withdrawal, J. Steroid. Biochem. 22 (1985) 687-691.

[17] Lessey B.A., Wahawisan R., Gorell T.A., Hormonal regulation of cytoplasmic estrogen and progesterone receptors in the beagle uterus and oviduct, Mol. Cell. Endocrinol. 21 (1981) 171-180.

[18] Lowry O.H., Rosebrough N.J., Farr A.L., Randall R.J., Protein measurement with the folin phenol reagent, J. Biol. Chem. 193 (1951) 265-275.

[19] Mathews L.S., Norstedt G., Palmiter R.D., Regulation of insulin-like growth factor-I gene expression by growth hormone, Proc. Natl. Acad. Sci. USA 83 (1986) 9343-9347.

[20] Medlock K.L., Lyttle C.R., Kelepouris N., Newman E.D., Sheehan D.M., Estradiol downregulation of the rat uterine estrogen receptor, Proc. Soc. Exp. Biol. Med. 196 (1991) 293-300.

[21] Medlock K.L., Forrester T.M., Sheehan D.M. Progesterone and estradiol interaction in the regulation of rat uterine weight and estrogen receptor concentration, Proc. Soc. Exp. Biol. Med. 205 (1994) 146-153.

[22] Meikle A., Tasende C., Rodríguez M. Garófalo E.G., Effects of estradiol and progesterone on the reproductive tract and on uterine sex steroid receptors in female lambs, Theriogenology 48 (1997) 1105-1113.

[23] Meikle A., Tasende C., Garófalo E.G., Forsberg M., Priming effect of exogenous oestradiol on luteinizing hormone secretion in prepubertal lambs, Anim. Reprod. Sci. 54 (1998) 75-85.

[24] Melton D.A., Krieg P.A., Rebagliati M.R., Maniatis R., Zinn K., Green M.R., Efficient in vitro synthesis of biologically active RNA and RNA hybridization probes from plasmids containing bacteriophage SP6 promotor, Nucleic Acids Res. 12 (1984) 7035-7056.

[25] Miller B.G., Murphy L., Stone G.M., Hormone receptor levels and hormone, RNA and protein metabolism in the genital tract during the oestrous cycle of the ewe, J. Endocrinol. 73 (1977) 91-98.

[26] Ortí E., Bodwell J.E., Munck A., Phosphorylation of steroid hormone receptors, Endocr. Rev. 13 (1992) 105-128.

[27] Ott T.L., Zhou Y., Mirando M.A., Stevens C., Harney J.P., Ogle T.F., Bazer F.W., Changes in progesterone and oestrogen receptor $\mathrm{mRNA}$ and protein during maternal recognition of pregnancy and luteolysis in ewes, J. Mol. Endocrinol 10 (1993) 171-183.

[28] Parczyk K., Madjno R., Michna H., Nishino Y., Schneider M.R., Progesterone receptor repression by estrogens in rat uterine epithelial cells, J. Steroid Biochem. Mol. Biol. 63 (1997) 309-316. 
[29] Perrot-Applanat M., Guiochon-Mantel A., Milgrom E., Immunolocalization of steroid hormone receptors in normal and tumour cells: mechanisms of their cellular traffic, Cancer Surv. 14 (1992) 5-30.

[30] Persson E., Sahlin L., Masironi B., Dantzer V., Eriksson H., Rodríguez-Martínez H., Insulinelike growth factor-I in the porcine endometrium and placenta. Localization and concentration in relation to steroid influence, Anim. Reprod. Sci. 46 (1997) 261-281.

[31] Rexroad C.E. Jr, Estrogen and progestogen binding in the myometrium of the ewe. I. During the estrous cycle, J. Anim. Sci. 53 (1981) 1057-1069.

[32] Rexroad C.E. Jr, Estrogen and progestogen binding in the myometrium of the ewe. II. Regulation by estradiol and progesterone, J. Anim. Sci. 53 (1981) 1070-1076.

[33] Rosser M., Chorich L., Howard E., Zamorano P., Mahesh V.B., Changes in rat uterine estrogen receptor messenger ribonucleic acid levels during estrogen- and progesterone- induced estrogen receptor depletion and subsequent replenishment, Biol. Reprod. 48 (1993) 89-98.

[34] Sahlin L., Norstedt G., Eriksson H., Estrogen regulation of the estrogen receptor and insulinelike growth factor-I in the rat uterus: a potential coupling between effects of estrogen and IGF-I, Steroids 59 (1994) 421-430.
[35] Spencer T.E., Bazer F.W., Temporal and spatial alterations in uterine estrogen receptor and progesterone receptor gene expression during the estrous cycle and early pregnancy in the ewe, Biol. Reprod. 53 (1995) 1527-1543.

[36] Stone G.M., McCaffery C., Miller B.G., Effects of progesterone on nuclear and cytosol steroid receptor levels in the oestrogen-stimulated uterus: comparison of the sheep and mouse, Aust. J. Biol. Sci. 35 (1982) 403-415.

[37] Tasende C., Meikle A., Rubianes E., Garófalo E.G., Restoration of estrogen and progesterone uterine receptors during the ovine postpartum period, Theriogenology 45 (1996) 1545-1551.

[38] Wu W.X., Owiny J., Zhang Q., Ma X.H., Nathanielsz P.W., Regulation of the estrogen receptor and its messenger ribonucleic acid in the ovariectomized sheep myometrium and endometrium: the role of estradiol and progesterone, Biol. Reprod. 55 (1996) 762-768.

[39] Zhou Y., Chorich L.P., Mahesh V.B., Ogle T.F., Regulation of estrogen receptor protein and messenger ribonucleic acid by estradiol and progesterone in rat uterus, J. Steroid Biochem. Mol. Biol. 46 (1993) 687-698.

[40] Zou K., Ing N.H., Oestradiol up-regulates oestrogen receptor, cyclophilin, and glyceraldehyde phosphate dehydrogenase mRNA concentrations in endometrium, but down-regulates them in liver, J. Steroid Biochem. Mol. Biol. 64 (1998) 231-237. 